\title{
Ceratocystis fimbriata Employs a Unique Infection Strategy Targeting Peltate Glandular Trichomes of Sweetpotato (Ipomoea batatas) Plants
}

\author{
Yong Sun, ${ }^{1}$ Mengqiu Li, ${ }^{1}$ Yansu Wang, ${ }^{1}$ Lianwei Li, ${ }^{1}$ Meng Wang, ${ }^{1}$ Xintong Li, ${ }^{1}$ Mengke Xu, ${ }^{1}$ Gary J. Loake, $, 2,3$ Ming \\ Guo, ${ }^{1, \dagger}$ and Jihong Jiang $1,2, \dagger$ \\ ${ }^{1}$ The Key Laboratory of Biotechnology for Medicinal Plants of Jiangsu Province, Jiangsu Normal University, Xuzhou 221116, Jiangsu, \\ P.R. China \\ 2 Jiangsu Normal University-Edinburgh University, Centre for Transformative Biotechnology of Medicinal and Food Plants, Jiangsu Normal \\ University, 101 Shanghai Road, Xuzhou, P.R. China \\ ${ }^{3}$ Institute of Molecular Plant Sciences, School of Biological Sciences, Edinburgh University, King's Buildings, Mayfield Road, Edinburgh EH9 \\ 3JR, U.K. \\ Accepted for publication 15 July 2020.
}

\begin{abstract}
The infection processes of Ceratocystis fimbriata BMPZ13 (BMPZ13) was elucidated on vegetative tissues of sweetpotato plants employing light and scanning electron microscopy. Vegetative tissues infected with C. fimbriata BMPZ13 by either wounding or nonwounding inoculation methods developed typical disease symptoms, establishing black rot in stems and necrosis on buds, young leaves, and stems of sprouts, in addition to wilt on leaves and shoot cuttings, typical of vascular associated diseases. The runner hyphae of $C$. fimbriata BMPZ13 formed from germinated conidia were able to directly penetrate the epidermal cuticle for initial infection and invade sweetpotato peltate glandular trichomes, specialized secretory structures to store and secrete metabolites. A two-step biotrophic phase was observed with nonwounding inoculation on leaves and stems, featuring both intercellular and intracellular invasive hyphae, with the latter found within living cells of

the leaf epidermis. Subsequent to the biotrophic phase was a necrotrophic phase displaying cell death in infected leaves and veins. Additionally, this cell death was an iron-associated ferroptosis, supporting the notion that iron is involved in the necrotrophic phase of C. fimbriata BMPZ13 infection. Significantly, we establish that $C$. fimbriata employs a unique infection strategy: the targeting of peltate glandular trichomes. Collectively, our findings show that $C$. fimbriata is a plant fungal pathogen with a hemibiotrophic infection style in sweetpotato vegetative tissues.

Keywords: biochemistry and cell biology, Ceratocystis fimbriata, etiology, ferroptosis, hemibiotroph, mycology, necrotrophic phase, peltate glandular trichomes, postharvest pathology and mycotoxins, sweetpotato black rot, vegetative infection
\end{abstract}

Sweetpotato [Ipomoea batatas (L.) Lam.] is one of the most widely cultivated storage root crops, especially in tropical and subtropical countries (Lebot 2009; Scott et al. 2000). Key attributes of sweetpotato relative to other major staple food crops include a wide range of production geography, excellent adaptability to marginal soils, climate conditions, and high nutritional values. Sweetpotato is consumed as food, utilized as a reliable feed for livestock and even is employed as a medicinal plant (Panda and Sonkamble 2012). It is an excellent source of nutrients including provitamins, vitamin $\mathrm{C}$, potassium, iron, and calcium minerals (Clark and Moyer 2013). Sweetpotato serves as a staple food in many countries of subtropical regions because the storage roots are rich in starch and the leaves and young shoots are edible (Lim 2016). Sweetpotato has also drawn attention as an emerging alternative to established bioenergy crops (Qiu et al. 2010; Wang et al. 2013).

†Corresponding authors: J. Jiang; jhjiang@jsnu.edu.cn, and M. Guo; mguo2@unl.edu

Current address of M. Guo: Department of Agronomy and Horticulture, N307 Beadle Center, University of Nebraska, Lincoln, U.S.A.

Funding: This work was supported by the National Natural Science Foundation of China grant 31770613 to J. Jiang and Natural Science Foundation of Jiangsu Province grant BK20171164 to M. Guo.

*The $e$-Xtra logo stands for "electronic extra" and indicates there are supplementary materials published online.

The author(s) declare no conflict of interest.

C 2020 The American Phytopathological Society
Black rot disease is one of the most important fungal diseases of sweetpotato, causing significant losses in yield and a drastic decrease in quality ( $\mathrm{Li}$ et al. 2009). The causative agent of black rot disease is $C$. fimbriata, which has a worldwide distribution in sweetpotato growing regions (Zauza et al. 2004). The $C$. fimbriata complex consists of multiple species which infect a range of host plants. Three host-specific lineages of $C$. fimbriata were identified from cacao (Theobroma cacao), sweetpotato (Ipomoea batatas), and sycamore (Platanus spp.) (Engelbrecht et al. 2004; Harrington et al. 2005). C. fimbriata also causes wilt and canker diseases in a wide range of woody hosts including: kiwifruit (Actinidia spp.) (Piveta et al. 2016), ficus (Ficus carica) (Pasura and Harrington 2004), yerba mate (Ilex paraguariensis) (Dos Santos et al. 2018), Eucalyptus, mango (Mangifera indica L.) (Araujo 2014), plane tree (Platanus spp.) (Clerivet et al. 2000), and pomegranate (Punica granatum) (Harrington et al. 2015). Besides sweetpotato, other herbaceous nonwoody hosts are also infected by $C$. fimbriata strains causing rot diseases including taro (Colocasia esculenta) and Peruvian carrot (Arracacia xanthorrhiza) (Harrington et al. 2005; Johnson et al. 2005; Melo et al. 2016). During cultivation and postharvest storage, typical annual yield losses caused by sweetpotato black rot are 5 to $10 \%$, but can be significantly greater in exceptional years (Zhang et al. 2017).

Phytoalexin substances are produced in sweetpotato as a mechanism of defense against C. fimbriata infection (Oguni and Uritani 1974). Some of these defense-related furanoterpenoid derivatives, when accumulated heavily in infected sweetpotato storage roots, are toxic to humans and animals. For example, the notorious ipomeamarone is poisonous to both humans and livestock (Akazawa and Uritani 1961; Akazawa and Wada 1961; Imaseki and 
Ikuzo 1964; Wamalwa et al. 2015), with accidental consumption of diseased sweetpotato storage roots often leading to serious health concerns for humans, and the death of livestock (Coxon et al. 1975).

Plant fungal pathogens infect and interact with their host plants through a number of distinct mechanisms including biotrophic, necrotrophic, and hemibiotrophic lifestyles (Presti et al. 2015). Biotrophs invade and propagate in living cells, while necrotrophs kill host cells and feed off the nutrients released from dead tissues. Hemibiotrophic pathogens initiate a biotrophic phase after entering plant tissues and then switch to necrotrophy (Kabbage et al. 2015). Recently, necrosis associated with plant pathogenic fungal infection has been linked to ferroptosis, an iron-dependent ferroptotic cell death, which plays a key role in the interaction of rice with the hemibiotrophic fungal pathogen Magnaporthe oryzae (Dangol et al. 2019). Hemibiotrophic pathogens typically enter host cells by mechanical penetration of the cuticle by employing dome-shaped and melanized appressoria, or enter via natural openings such as stomata (De Wit 1977; Tucker and Talbot 2001). Whether alternative strategies are used by plant fungal pathogens to enter host tissues remain to be established.

Black rot of sweetpotato is generally considered to be a seedborne and soilborne postharvest disease because $C$. fimbriata infects sweetpotato storage roots through wounds during postharvest storage, however, severe diseases occur in seed beds and during vegetative growth in the field, including plant stunting, wilting, yellowing, leaf drop, and death (Clark and Moyer 2013; Hildebrand and Cook 1959). C. fimbriata is believed to be a necrotrophic pathogen, at least on storage roots (Johnson et al. 2005). Much attention was paid to black rot disease of storage roots, while relatively little is known about the infection style of $C$. fimbriata on sweetpotato vegetative tissues either in the field or under laboratory conditions. Thus, the $C$. fimbriata-sweetpotato pathosystem warrants detailed characterization of $C$. fimbriata infection on vegetative tissues of sweetpotato plants. In this context, it is important to determine the possible role of any vegetative infection in disease cycles of black rot in the field, and the resulting impact on disease occurrence at the postharvest storage stage.

Our study aimed to determine whether $C$. fimbriata possessed the capability to infect sweetpotato vegetative tissues, and if so, whether the pathogenic lifestyle on vegetative tissues is different from that on storage roots and of other plant fungal pathogens. This information may help guide future control strategies for C. fimbriata infection of sweetpotato.

\section{MATERIALS AND METHODS}

The fungal strain and culture conditions. C. fimbriata BMPZ13 was provided by the Sweet Potato Research Center at Xuzhou Academy of Agricultural Sciences, Jiangsu, China. This particular strain was isolated from a sweetpotato exhibiting typical symptoms of black rot in the field in Xuzhou. C. fimbriata BMPZ13 is a representative strain that is virulent in many varieties including Guishu 07-98 (data not shown). The mycelia of C. fimbriata BMPZ13 was cultured on potato dextrose agar (PDA) in an incubator at $25^{\circ} \mathrm{C}$ in the dark or potato dextrose broth at $25^{\circ} \mathrm{C}$ in a shaker at $150 \mathrm{rpm}$.

Fungal genomic DNA extraction. Acetyl trimethyl ammonium bromide (CTAB)-based DNA extraction protocol was adapted with minor modification (Murray and Thompson 1980). The colonies were grown on PDA plates for 3 to 4 days to around 1.2 to $1.5 \mathrm{~cm}$ in diameter. A mycelium mass of $1 \mathrm{~cm}$ (about $3 / 4$ of the colony) was mixed with quartz sand in an Eppendorf tube and frozen at $-20^{\circ} \mathrm{C}$ followed by an incubation with $200 \mu \mathrm{l}$ of $2 \% \mathrm{CTAB}$ at $65^{\circ} \mathrm{C}$ for $1 \mathrm{~h}$. An equal volume of phenol/chloroform/isoamyl alcohol (25:24:1) was added and vigorously shaken for $1 \mathrm{~min}$ followed by centrifugation at $12,000 \mathrm{rpm}$ for $10 \mathrm{~min}$. The aqueous phase was mixed with two volumes of $100 \%$ ethanol and incubated at $-20^{\circ} \mathrm{C}$ for $2 \mathrm{~h}$. Fungal genomic DNA was then pelleted by centrifuging at 12,000 rpm for $10 \mathrm{~min}$ and washed with $75 \%$ ethanol. Air dried fungal genomic DNA pellets were dissolved in $\mathrm{ddH}_{2} \mathrm{O}$ and stored at $-20^{\circ} \mathrm{C}$ for later use.

Identification of ITS and LSU rDNA. The conserved sequences among fungal pathogens of two genomic regions, internal transcribed spacer (ITS) and large subunit ribosomal DNA (LSU rDNA), were determined using a procedure previously reported (Baker et al. 2003). The primers for PCR amplification are listed in Supplementary Table S1. The ITS region including 5.8S rDNA operon was amplified by PCR with primers ITS4 and ITS5 (Supplementary Table S1). LSU rDNA region was amplified with primers LROR and LR5 (Supplementary Table S1) (Stielow et al. 2015). Taq DNA polymerase-based PCR amplification was conducted in a BIOER LifePro Thermal cycler PCR System (Hangzhou Bioer Technology Co. Ltd., China) with the following thermocycling conditions: initial denaturation at $94^{\circ} \mathrm{C}$ for $5 \mathrm{~min}$, followed by 35 cycles of $94^{\circ} \mathrm{C}$ for $30 \mathrm{~s}$, and $55^{\circ} \mathrm{C}$ for $30 \mathrm{~s}$, and $72^{\circ} \mathrm{C}$ for $2 \mathrm{~min}$, and then a final extension at $72^{\circ} \mathrm{C}$ for $10 \mathrm{~min}$. The amplified PCR products were purified from agarose gels and sequenced in both directions by a commercial sequencing service provider (Sangon Biotech, Shanghai, China).

Sequence analysis. The resulting sequences were compared with ITS or LSU rDNA sequences in GenBank database at the National Center for Biotechnology Information (NCBI) (https:// www.ncbi.nlm.nih.gov) using basic local alignment search tool (BLAST) (Altschul et al. 1990). Phylogenetic analysis was performed using MEGA 6 and a maximum likelihood phylogenetic tree was constructed with combined datasets of the ITS and LSU rDNA sequences (Tamura et al. 2013). Sequences were deposited in GenBank and assigned accession numbers MN396458 and MN396459.

Plant material. Sweetpotato variety Guishu 07-98 was provided by Jinfeng Hua at Guangxi Academy of Agricultural Sciences, Guangxi, China. Sweetpotato storage roots were kept in pots filled with sandy soil within a greenhouse of $75 \%$ relative humidity and $16 \mathrm{~h}$ of lighting at $25^{\circ} \mathrm{C}$. Sprout development usually started in 10 to 18 days. One-month-old shoots (12 to $15 \mathrm{~cm}$ long) were detached and then transplanted individually into pots for rooting and maintained to grow to 30 to $45 \mathrm{~cm}$ tall in greenhouse. Different types of sweetpotato vegetative tissues were used in pathogenicity assays and for the purposes of microscopic experiments.

Pathogenicity assay. C. fimbriata BMPZ13 was cultured for 7 to 10 days on PDA. Conidia were flushed with $1 \mathrm{ml}$ of distilled water and collected in Eppendorf tubes. Mycelium mass was removed by filtering conidia spore suspension through a cheese cloth. The spores were pelleted by centrifugation at 3,000 rpm for $10 \mathrm{~min}$ and washed twice with $1 \mathrm{ml}$ of distilled water. The conidia were resuspended with $1 \mathrm{ml}$ of distilled water, and the numbers were counted with a hemocytometer under $10 \times$ magnification. A final spore resuspension for inoculation was adjusted to $1 \times 10^{5} \mathrm{spores} / \mathrm{ml}$ for inoculations.

Pathogenicity assays involved nonwounding and wounding inoculation methods. For nonwounding inoculation, 8-day-old sprouts (usually 4 to $6 \mathrm{~cm}$ in length) with unfolded young leaves were spray-inoculated with $1 \mathrm{ml}$ of $C$. fimbriata BMPZ13 spore suspension using a small atomizer ( $10 \mathrm{ml}$ volume) for nonwounding inoculations. In each independent assay, six detached sweetpotato sprouts were spray-inoculated with $C$. fimbriata BMPZ13 on young stems and leaves and $\mathrm{H}_{2} \mathrm{O}$ as mock treatment. For nonwounding inoculation of detached leaves, six fully expanded sweetpotato leaves were drop-inoculated by spotting a $2-\mu \mathrm{l}$ spore suspension on one half of the leaves. A mock inoculation was distilled $\mathrm{H}_{2} \mathrm{O}$ on the other half. The inoculated sweetpotato sprouts or leaves were placed in petri dishes with a layer of wet filter paper for maintaining moisture for 9 days to monitor disease development.

Wounding inoculation was used for pathogenicity assays on sweetpotato storage roots, fully expanded leaves and shoot cuttings. 
Six storage roots were pierced $0.5 \mathrm{~cm}$ deep with a needle and injected with $20 \mu \mathrm{l}$ of spore suspension. The inoculated storage roots were maintained in a growth chamber at $25^{\circ} \mathrm{C}$ with $16 \mathrm{~h}$ of lighting and $75 \%$ relative humidity. Six fully expanded leaves were wounded with needle and each wounding site was drop-inoculated by spotting with $2 \mu \mathrm{l}$ of spore suspension. The inoculated tissues were maintained in a growth chamber under the same conditions as for storage roots, and disease development was monitored for 14 days for disease progression and symptom development. A mock inoculation with distilled $\mathrm{H}_{2} \mathrm{O}$ was made as the control. Six shoot cuttings of sweetpotato plants were inoculated at the base with $300 \mu \mathrm{l}$ of $C$. fimbriata BMPZ13 spore suspension at $1 \times 10^{5}$ spores/ $\mathrm{ml}$ and distilled $\mathrm{H}_{2} \mathrm{O}$ employed as a mock treatment. The inoculated cuttings were kept in a growth chamber with the same conditions above and monitored for disease progression and symptom development for up to 21 days.

All the pathogenicity assays were repeated three times for both symptom development and microscopic observation. For pathogenicity assays involving in nonwounding drop inoculation, half of the inoculated tissues were kept for disease symptom development while the other half were collected as samples for light microscope and scanning electron microscope (SEM) observation.

Leaf tissue clearing. For clear visualization of infected tissues under microscope, the leaf tissues were cleared by removing chlorophyll. A leaf tissue clearing protocol was adapted from the previously reported method with modification (Xie et al. 2018). Leaves were drop-inoculated without wounding and tissue samples of inoculated area were taken at time points $0,4,6$, and $8 \mathrm{~h}$, and 1, 2, $3,5,7$, and 10 days after inoculation. The tissue samples were fixed in formaldehyde acetic acid (FAA) solution at $4^{\circ} \mathrm{C}$ overnight followed with washes of phosphate buffered saline (PBS), $\mathrm{pH} \mathrm{7.4,}$ twice. The fixed tissues were subjected to a dehydration procedure with a serial ethanol solutions: $50 \%$ ethanol for $1 \mathrm{~h}, 70 \%$ ethanol for $1 \mathrm{~h}, 90 \%$ ethanol for $1 \mathrm{~h}$, and finally $100 \%$ ethanol for $3 \mathrm{~h}$. The dehydrated samples were then immersed in $10 \%$ potassium hydroxide solution for $2 \mathrm{~h}$ and gently mounted on slides for light microscopic visualization with a Leica DM5000 B light microscope.

Histochemical Prussian blue staining of $\mathrm{Fe}^{3+}$ accumulation. A protocol for Prussian blue $\mathrm{Fe}^{3+}$ staining was followed as previously described for other fungal infections with slight modification (Dangol et al. 2019; Liu et al. 2007). Young leaves or stems of 8-day-old sweetpotato sprouts were spray-inoculated with a C. fimbriata BMPZ13 spore suspension. The epidermal peels of leaves or stems were sampled at time 0 and 4 days postinoculation and incubated in $7 \%(\mathrm{wt} / \mathrm{vol})$ potassium ferrocyanide and $2 \%$ (vol/ vol) hydrochloric acid $(\mathrm{HCl})(1: 1, \mathrm{vol} / \mathrm{vol})$ for $15 \mathrm{~h}$ at room temperature. Bright Prussian blue pigments, or ferric ferrocyanides resulted from reaction of $\mathrm{Fe}^{3+}$ with ferrocyanides inside leaf or stem epidermal cells. Experiments were repeated three times to observe and document Prussian blue pigment accumulation with a Leica DM5000 B light microscope.

Trypan blue staining. To monitor the C. fimbriata BMPZ13 hyphal progression and visualize cell death of infected cells, a Trypan blue staining previously described was adapted with slight modifications (Koch and Slusarenko 1990; Takemoto et al. 2003). Sweetpotato leaves were infected with either wounding or nonwounding drop inoculation methods. Four days postinoculation, six disc ( $1 \mathrm{~cm}$ in diameter) of the infected or mock-treated leaf tissues were cleared in ethanol for $24 \mathrm{~h}$ and stained by boiling for $3 \mathrm{~min}$ in lactophenol trypan blue solution $\left(10 \mathrm{ml}\right.$ of $\mathrm{H}_{2} \mathrm{O}, 10 \mathrm{ml}$ of lactic acid, $10 \mathrm{ml}$ of glycerol, $10 \mathrm{~g}$ of phenol, and $10 \mathrm{mg}$ of trypan blue) followed with cooling to a room temperature. The stained tissues were destained with chloral hydrate solution at $1 \mathrm{~g} / \mathrm{ml}$ by boiling for $20 \mathrm{~min}$ and visualized under a Leica DM5000B microscope. Experiments were repeated three times.

Light microscope. A Leica DM5000 B light microscope (Leica, Germany) was used for visualization and imaging of samples. Culture samples were directly mounted for microscopic observation of microstructures and the sizes of microstructures were measured with an internal ruler and Leica imaging software. Measurements of 60 microstructures were recorded of each type. Other samples include peels of live epidermis, cleared or stained sweetpotato tissues either inoculated or mock treated at the indicated time points.

SEM. A procedure of fixation previously reported was modified for SEM sample preparation (Cai et al. 2008). Leaves and sprouts were infected with $C$. fimbriata BMPZ13 by nonwounding inoculation method. After infection, 10 epidermal peels of inoculated leaves or stems of sprouts were collected at 6, 24, 48, 72 , and $96 \mathrm{~h}$ after inoculation. Samples were washed with $0.1 \mathrm{M}$ phosphoric acid buffer ( $\mathrm{pH}$ 7.2) for 15 min three times following a fixation in $1 \%$ osmium acid liquid for $2 \mathrm{~h}$. The fixed tissues were dehydrated with ethanol at a concentration gradient of 30, 50, 60, $70,80,90,95$, and $100 \%$, for $30 \mathrm{~min}$ at each concentration. The ethanol dehydrated tissues were then subjected to critical point drying with Leica EM CPD030 critical point dryer. The dried tissues were coated with gold and mounted for observation by SEM S3400.

\section{RESULTS}

Identification and microstructures of $C$. fimbriata BMPZ13. Species identification and pathogenicity of $C$. fimbriata BMPZ13 was determined on a number of sweetpotato varieties displaying typical black rot disease symptoms (data not shown). To confirm the species identification of $C$. fimbriata BMPZ13, the ITS and LSU regions were PCR-amplified and sequenced. Sequence comparison showed that ITS of $C$. fimbriata BMPZ13 was identical to those of four isolates in China from Ipomoea batatas and shared a $99.84 \%$ sequence identity to those of Korean sweetpotato isolates (SPL17100 and SPL17101). Similarly, the LSU sequence of $C$. fimbriata BMPZ13 was identical to those of other sweetpotato strains. A phylogenetic analysis determined that BMPZ13 was present in the same clade with reference strains (SPL17100, SPL17101, CMW15049, CBS103.40, and CBS114723) and Chinese strains (Li et al. 2016a, b) (Supplementary Fig. S1).

The $C$. fimbriata BMPZ13 culture became yellowish brown with a smell of fruity odor after incubation on PDA at $25^{\circ} \mathrm{C}$ for 7 days in the dark. C. fimbriata BMPZ13 developed all types of microstructures that were commonly seen with other $C$. fimbriata strains from sweetpotato, albeit with minor differences (Paul et al. 2018). The main characteristics and sizes of microstructures are listed in Table 1.

Flask-shaped conidiophore started to produce cylindrical singlecelled conidia after incubation for 5 days at $25^{\circ} \mathrm{C}$ under a $12 \mathrm{~h}$ light photoperiod (Fig. 1A to C). Aleuroconidiophores developed on PDA medium (Fig. 1D) producing rounded aleuroconidia (Fig. 1E and F). The globular perithecia were dark brown with slim necks and usually found near the center of the colony after incubation for 10 days at $25^{\circ} \mathrm{C}$ under a $12 \mathrm{~h}$ light photoperiod, of which the ostiole forming hyphae attenuated from the base to the tip (Fig. 1G). The ascospores produced were helmet-shaped (Fig. 1H and I).

C. fimbriata BMPZ13 infects vegetative tissues of sweetpotato. To determine how $C$. fimbriata BMPZ13 might cause disease through wounding, we assayed the pathogenicity of this fungus on storage roots and vegetative tissues, including shoot cuttings and leaves of the sweetpotato variety Guishu 07-98. When storage roots were inoculated at wound sites, Guishu 07-98 was susceptible to $C$. fimbriata BMPZ13 infection and developed typical black rot disease symptoms after about 7 days, similar to other strains on susceptible sweetpotato varieties (Fig. 2A, Supplementary Table S2) (Paul et al. 2018). Shoot cuttings were drop-inoculated at the base with a $C$. fimbriata BMPZ13 spore suspension. Symptoms of black rot or canker of stems near the inoculation sites appeared 9 days postinoculation. A more severe 
chlorosis of upper leaves started to appear about 14 days after inoculation. The wilt symptoms of the shoot developed 9 to 14 days after the appearance of stem cankers, typically followed by eventual death (Fig. 2C on the left, Supplementary Table S2).

TABLE 1. Characteristics of microstructures of Ceratocystis fimbriata BMPZ13

\begin{tabular}{|c|c|c|}
\hline Microstructure & Size $(\mu \mathrm{m})$ & Characteristics \\
\hline Conidiophores & $6.5-8.9 \times 38.2-59.3$ & $\begin{array}{l}\text { Flask-shaped and produce } \\
\text { conidia (Fig. 1A) }\end{array}$ \\
\hline Conidia & $3.3-7.6 \times 6.8-40$ & Cylindrical (Fig. 1B and C) \\
\hline Aleuroconidiophores & $4.8-9.2 \times 10.4-48.7$ & Produce aleuroconidia (Fig. 1D) \\
\hline Aleuroconidia & $8.3-13.2 \times 11.9-20.4$ & $\begin{array}{l}\text { Round, thick walls, slightly } \\
\text { brown (Fig. 1E and F) }\end{array}$ \\
\hline Perithecia & $\begin{array}{l}\text { Base: } 161.3-343.7 \\
\text { Neck: } 446.3-627.6 \\
\text { Ostiole forming } \\
\text { hyphae: } 22.3-35.2 \\
\text { Ostiole diameter: } \\
14.9-24.7\end{array}$ & $\begin{array}{l}\text { Globular, dark brown (Fig. } \\
1 \mathrm{G})\end{array}$ \\
\hline Ascospores & $4.3-6.6 \times 5.9-8.4$ & Helmet-shaped (Fig. 1H and I) \\
\hline
\end{tabular}

All leaves inoculated through wound sites developed typical symptoms of necrosis around the inoculation site and fine veins turned necrotic beyond the inoculation site (Fig. 2D, left), while no symptoms were seen following mock inoculation (Fig. 2D, right). Moreover, necrotic lesions were developed on all wound-inoculated leaves at locations distal from inoculation sites and C. fimbriata BMPZ13 could be recovered from these distal lesions (Supplementary Fig. S2).

After incubation of tissues inoculated through a nonwounding procedure in a growth chamber at $25^{\circ} \mathrm{C}$ with $16 \mathrm{~h}$ light and $8 \mathrm{~h}$ darkness, necrotic lesions developed on tender leaves and stems of sprouts at about 3 days after spray inoculation (Fig. 2E and F, Supplementary Table S2). Small microscopic necrosis developed on leaves 3 to 5 days after drop inoculation with $C$. fimbriata BMPZ13 (Fig. 2G), with typical necrotic veins and chlorosis appearing 7 to 10 day postinoculation (Fig. $2 \mathrm{H}$ ), while the mock treated leaves remained normal (Fig. 2I and 2J). When sweetpotato storage roots were spray- or drop-inoculated with spore suspensions in a nonwounding manner, only minor necrotic lesions were observed on adventitious buds, while no obvious symptoms developed on storage roots (data not shown). Time for disease
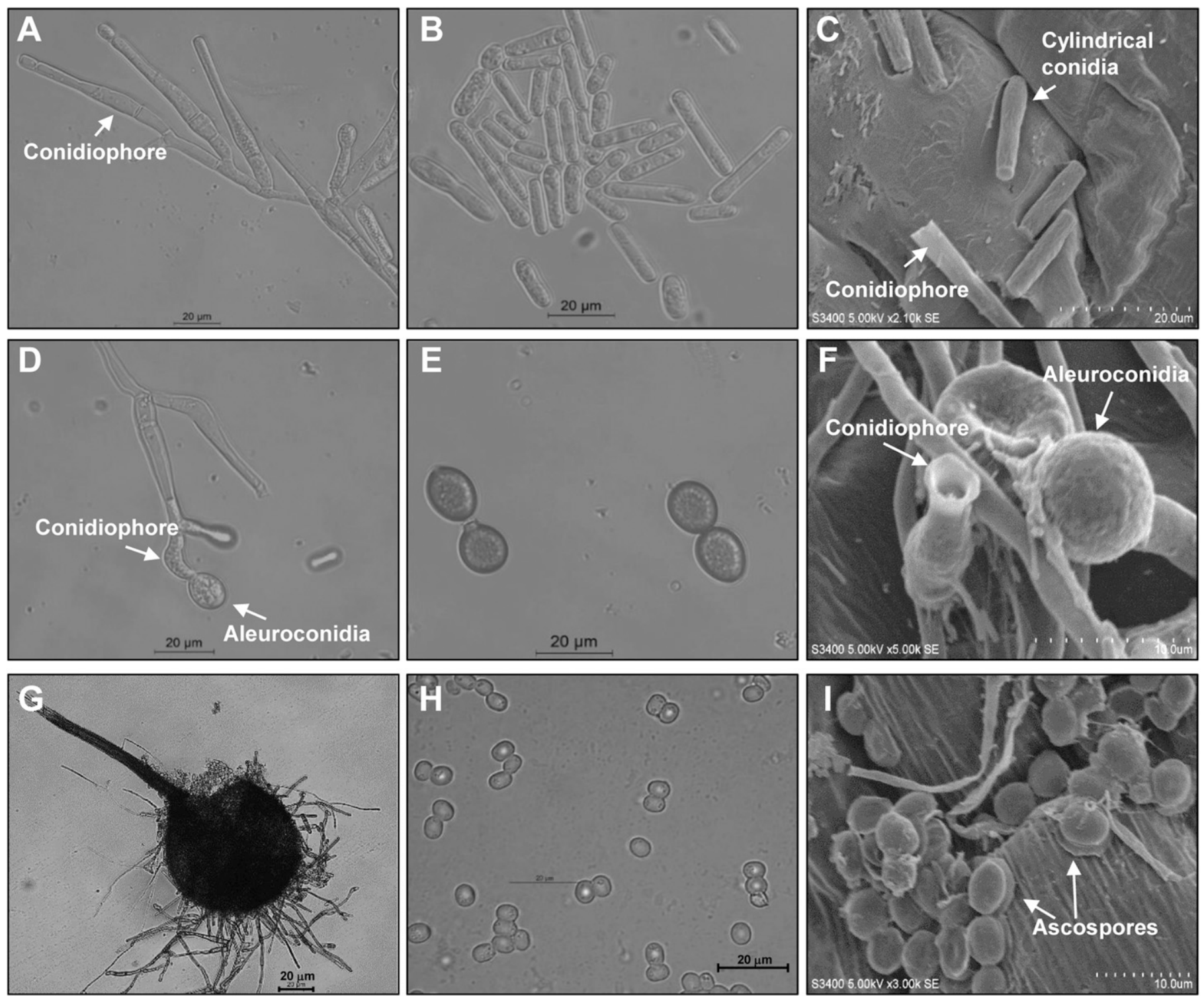

Fig. 1. Microstructures of Ceratocystis fimbriata BMPZ13. A, Conidiophore. B and C, Cylindrical conidia. D, Aleuroconidiophores. E, Aleuroconidia. F, Aleuroconidia and an endoconidium. G, Long neck perithecium. H and I, Ascospores. Microstructures of $C$. fimbriata BMPZ13 observed with light microscopy are shown in A, B, D, E, G, and $\mathrm{H}$ and scanning electron microscopy in $\mathrm{C}, \mathrm{F}$, and $\mathrm{I}$. 
development on different tissues varied slightly with different inoculation methods (Supplementary Table S2).

C. fimbriata BMPZ13 infection involves a two-step biotrophic phase. To elucidate the entry strategy and subsequent progression of $C$. fimbriata BMPZ13 infection in the absence of host wounding, a spray inoculation procedure was deployed, which more closely mimics natural infection. Young sprouts and leaves of sweetpotato variety Guishu 07-98 were spray-inoculated with a $C$. fimbriata
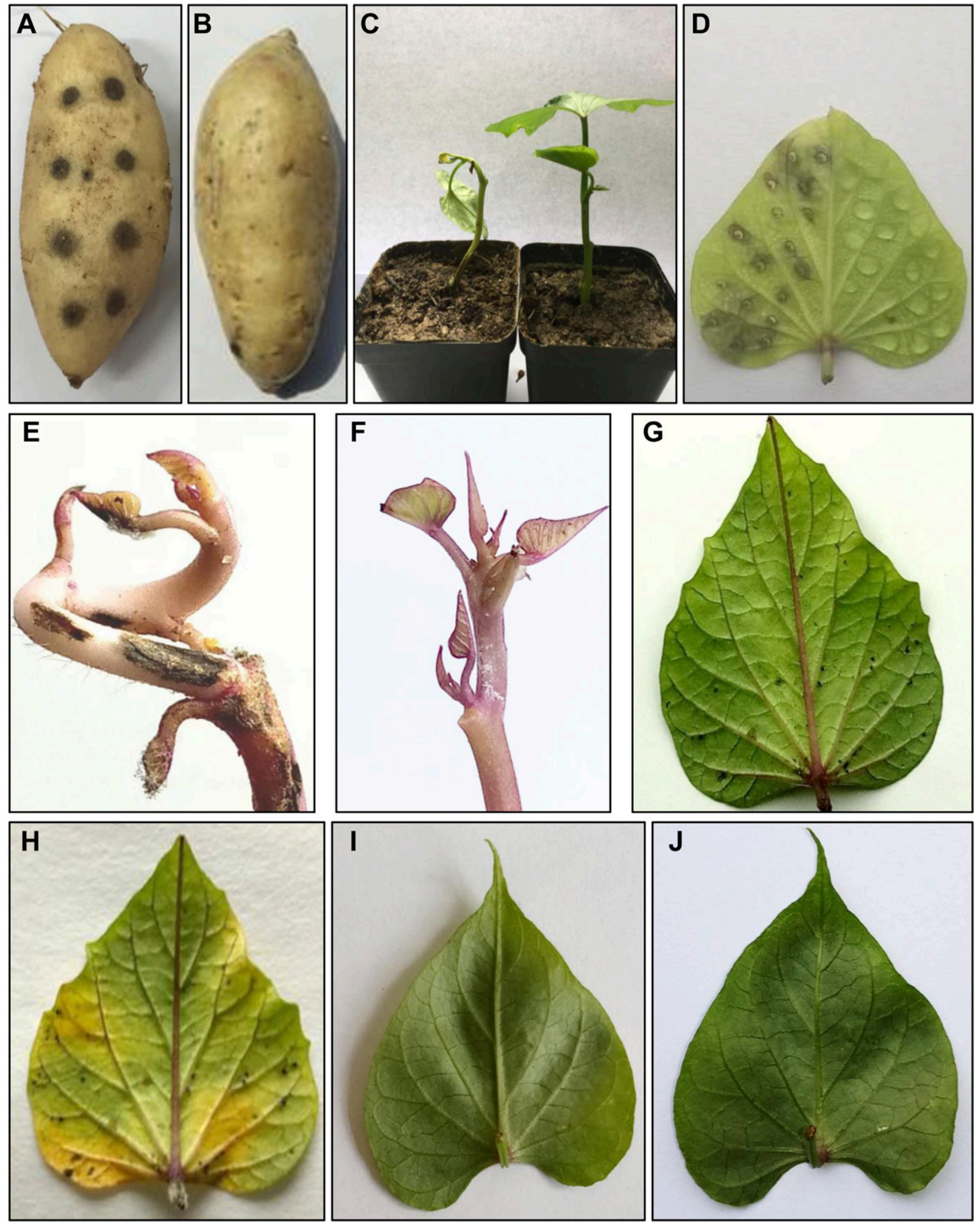

Fig. 2. Ceratocystis fimbriata BMPZ13 infects vegetative tissues of sweetpotato. A, Symptoms of storage root infected with $C$. fimbriata BMPZ13 8 days after wounding drop inoculation. B, Mock $\left(\mathrm{H}_{2} \mathrm{O}\right)$ inoculation control for A. C, Cutting infected (left) and mock inoculation (right). Shown are symptoms of wilt and rot on stem base 15 days after inoculation. D, Leaf infected by wounding drop inoculation (left) and mock (right) 5 days after inoculation. E, Symptoms of sprouts infected with nonwounding spray inoculation. Shown are the symptoms of young leaf and stems 5 days after inoculation. $\mathbf{F}$, Mock $\left(\mathrm{H}_{2} \mathrm{O}\right)$ inoculation control for E. $\mathbf{G}$ and $\mathbf{H}$, Symptoms of leaves 3 days $(\mathrm{G})$ and 9 days after nonwounding drop inoculation $(\mathrm{H})$. $\mathbf{I}$ and $\mathbf{J}$, Mock $\left(\mathrm{H}_{2} \mathrm{O}\right)$ inoculation control for $\mathrm{G}$ and $\mathrm{H}$ at the same time points after inoculation, respectively. Pathogenicity assays were repeated three times with consistent results and disease symptoms. 
BMPZ13 spore suspension. The rod-shaped conidia asymmetrically germinated from one side of the middle cell, forming a T-shaped germinating tube structure within $6 \mathrm{~h}$ (Fig. 3A and Supplementary Fig. $\mathrm{S} 3 \mathrm{~A})$. The germinated tube developed a runner hypha and grew on the epidermal surface. Runner hyphae extended to several hundred micrometers in length and entered epidermal cells within $24 \mathrm{~h}$ or continued growing until reaching a suitable entry site. The majority of runner hyphae did not form special structures for penetration of the cuticle, typically penetrating directly $\sim 2$ days postinoculation (Fig. 3C, Supplementary Fig. S3A). Veins and stem epidermis were infected in a similar fashion (Supplementary Fig. S3C and D). However, hyphae with enlarged tips were observed occasionally $(<2 \%$ of total hyphal entry events) at penetration sites on the epidermis (Fig. 3B). Runner hyphae were also found to penetrate peltate glandular trichomes in $100 \%$ of observed samples infected 2 to 3 days after conidia germination (Fig. 3D, Supplementary Fig. S3E). Interestingly, peltate glandular trichomes were found to be more preferable sites for hyphal entry, accounting for 67.60 and $87.70 \%$ of total observed entry events on infected sprout stems and leaves, respectively, compared with 32.40 and $12.30 \%$ entry events that were direct cuticle penetration (Table 2). In contrast, no hyphal penetration of stoma was observed. Typically, C. fimbriata BMPZ13 runner hyphae bypassed stomata on the epidermis (Supplementary Fig. S3F).

After penetration of the epidermal layer, the runner hyphae differentiated into two types of invasive hyphae (IH): intercellular
IH and intracellular IH. Intercellular IH grew between epidermal and mesophyll cells before entering epidermal cells or leaf veins (Fig. 4A and B). Intercellular IH were less segmented and thicker than normal runner hyphae, with long tubular structures possessing a brown cell wall. Intercellular IH were the dominant IH forms during continuous infection between cells, especially around vascular bundles (Fig. 4A to E). Intracellular IH and intercellular IH could be transformed reciprocally. Intercellular IH entered living epidermal cells and transformed into irregular swollen oval-shaped and nodose intracellular IH (Fig. 4B and Supplementary Fig. S4A). Both intercellular IH and intracellular IH were observed in cells adjacent to peltate glandular trichomes (Fig. 4C).

Hyphae extended and reached the proximity of leaf veins 4 days after inoculation, and a large number of oval-shaped intracellular IH accumulated in the mesophyll cells surrounding vascular bundles (Fig. 4D and Supplementary Fig. S4B). Intercellular IH also abundantly grew along veins promoting continuous infection after 5 to 6 days in vascular tissues, eventually leading to whole leaf chlorosis (Fig. 4D and E, Supplementary Fig. S4B).

Intercellular hyphae were often seen to extend out of stoma (Fig. 4F, Supplementary Fig. S4C) or the leaf epidermal septum, at a late stage (7 to 10 days) of infection (Supplementary Fig. S4D). Conidia and aleuroconidia were produced on infected tissues generally at 7 days after inoculation (Supplementary Fig. S5A to D).
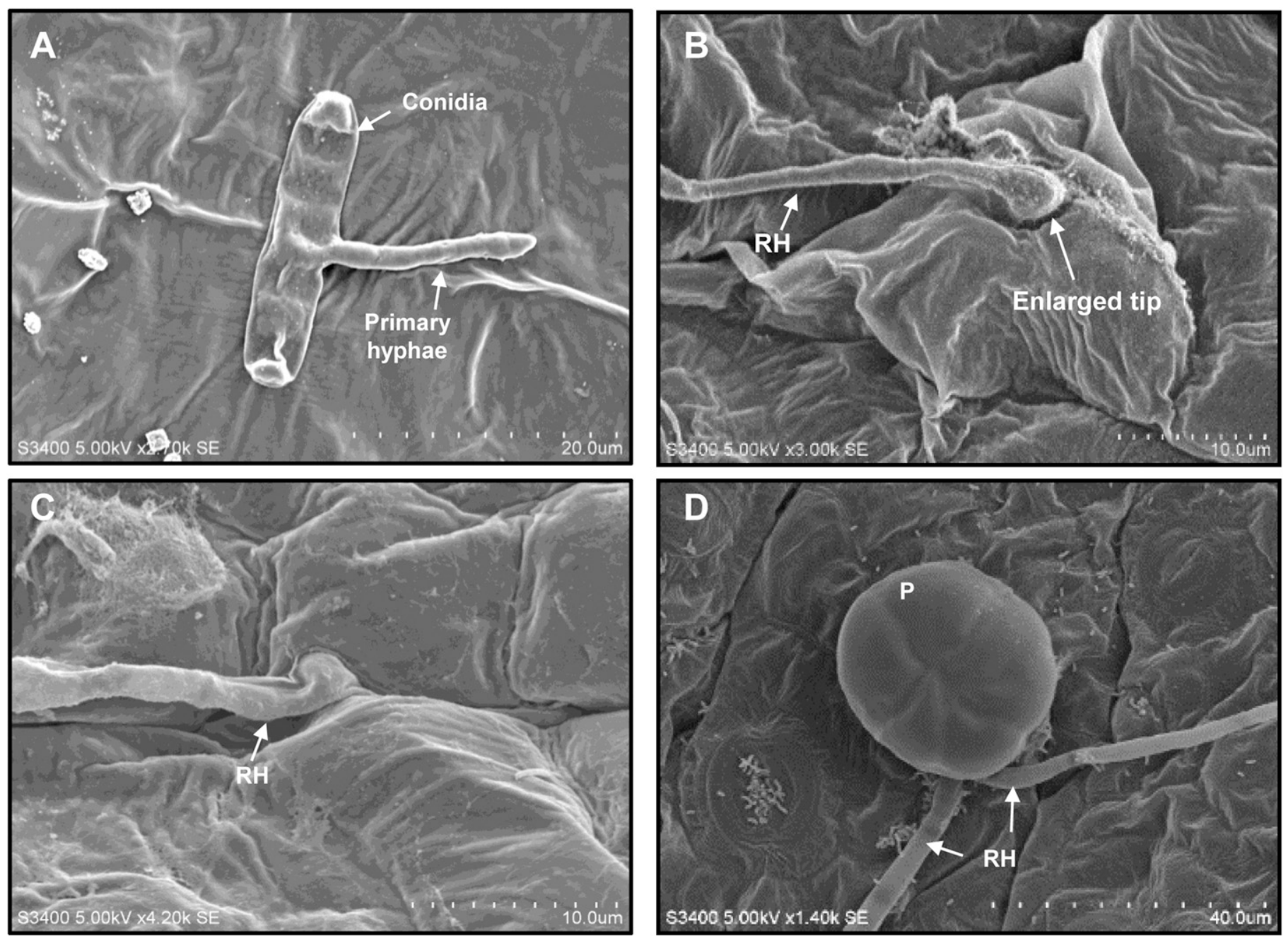

Fig. 3. Invasion of Ceratocystis fimbriata BMPZ13 into leaf tissues of sweetpotato. A, A germinating conidium on the leaf epidermis of sweetpotato. B, Enlarged tip of a C. fimbriata BMPZ13 hypha at the site of invasion 2 days postinoculation. C, An invasive hypha penetrating the epidermis of a sweetpotato leaf. D, Hyphae invading peltate glandular trichomes of sweetpotato. The leaf tissues (A to D) were infected with $C$. fimbriata BMPZ13 with the nonwounding drop inoculation method. RH, runner hyphae; P, peltate glandular trichome. 
Peltate glandular trichomes are targeted by $\boldsymbol{C}$. fimbriata BMPZ13. As peltate glandular trichomes were preferred penetration sites (Fig. 3D and 4C, Supplementary Table S2), the ability of $C$. fimbriata BMPZ13 to target peltate glandular trichomes was monitored. Directional growth of runner hyphae toward peltate glandular cells on the leaf epidermis was often observed (Fig. 5A). Subsequently, penetration typically ensued, followed by hyphae passing through the eight-cell-structured peltate glandular trichomes 2 to 3 days after spray inoculation (Fig. 5B). Growth of runner hyphae was routinely extended to other peltate glandular trichomes to form a hyphal network associated with these structures 5 days postinoculation (Fig. 5C). Runner hyphae developed lateral secondary hyphae, which also targeted peltate glandular trichomes 4 to 5 days after inoculation (Fig. 5D). Hyphae accumulated over time, eventually resulting in the destruction of peltate glandular trichomes 5 days after inoculation (Fig. 5E and F).

Necrotrophic phase of $C$. fimbriata BMPZ13 infection. Necrotrophic growth of $C$. fimbriata BMPZ13 was assessed with trypan blue staining to visualize cell death associated with infection (Joo et al. 2005; Koch and Slusarenko 1990; Takemoto et al. 2003). C. fimbriata BMPZ13 infection led to microscopic lesions (Fig. 6B), while mock inoculation on stems of sprouts resulted in no visible lesions (Fig. 6A). Necrotic lesions occurred as early as

TABLE 2. Frequency of hyphal penetration events into cuticle and peltate glandular trichomes

\begin{tabular}{lcccc}
\hline & Cuticle & $\begin{array}{c}\text { Peltate glandular } \\
\text { trichome }\end{array}$ & $\begin{array}{c}\text { Total penetration } \\
\text { events }\end{array}$ & $t$ test \\
\hline Stem & $32.40 \%$ & $67.60 \%$ & 68 & $P=0.00018$ \\
Leaf & $12.30 \%$ & $87.70 \%$ & 140 & $P=0.00417$ \\
\hline
\end{tabular}

4 days post-spray inoculation. Necrotic veins were commonly observed, which may have resulted from aggressive growth of $\mathrm{IH}$ (Figs. 6B and 4D and E). In contrast, wound inoculation led to more rapid cell death in the proximity of the inoculation site within 2 days, and similarly, necrotic veins extended to distal areas routinely at 4 days postinoculation (Fig. 6C).

Recently, iron-dependent ferroptotic cell death was reported in rice-Magnaporthe oryzae interactions (Dangol et al. 2019). To determine whether $C$. fimbriata BMPZ13 employs a similar mechanism in its necrotrophic growth, Prussian blue staining was applied to examine ferric accumulation at infection sites (Dangol et al. 2019; Liu et al. 2007). Blue pigment sedimentation was observed in cells of the stem of sprouts infected with $C$. fimbriata BMPZ13 2 days after spray inoculation, indicating iron accumulation is indeed involved in the interaction between sweetpotato and C. fimbriata (Fig. 6D and F). More interestingly, iron accumulation was also seen in cells adjacent to peltate glandular cells (Fig. 6E and F), consistent with C. fimbriata infection being linked to peltate glandular trichomes (Figs. 4C and 5).

\section{DISCUSSION}

ITS and LSU sequences of C. fimbriata BMPZ13 are identical to those of all Chinese isolates or share high similarity (99.84\%) to Korean isolates in the comparison (Supplementary Fig. S1). The measurements of microstructures were also similar to those reported (Paul et al. 2018). This indicates that $C$. fimbriata BMPZ13 is most likely the same lineage originating from the clonal haplotypes isolated from sweetpotato in China, supporting the hypothesis that $C$. fimbriata was introduced to Japan on sweetpotato storage roots and then introduced to China in the 1930s ( $\mathrm{Li}$ et al. 2016a, b).
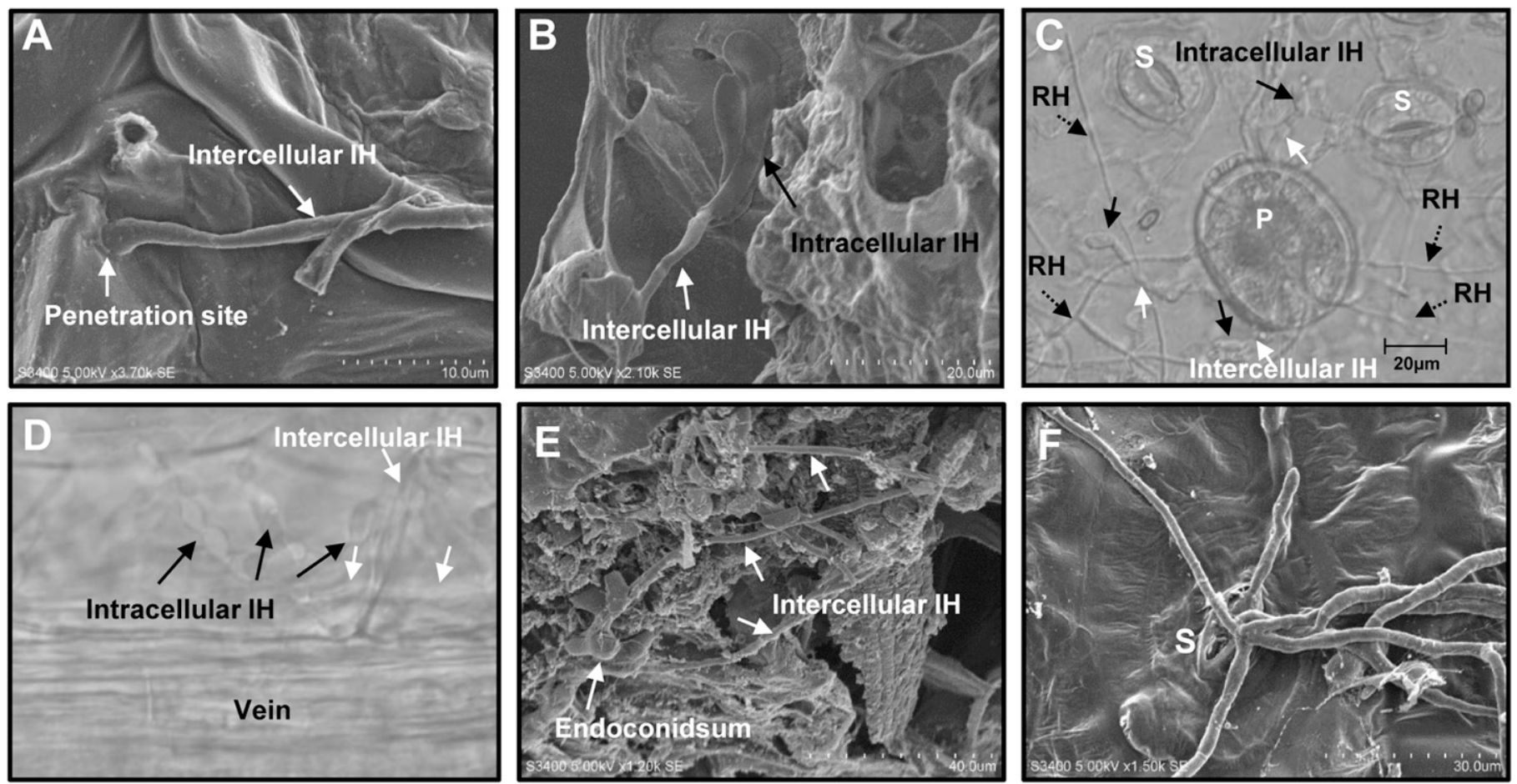

Fig. 4. Ceratocystis fimbriata BMPZ13 develops invasive hyphae (IH). A, An intercellular IH formed after penetration of the sweetpotato leaf cuticle. B, A tubular intercellular IH entering into a leaf epidermal cell of sweetpotato and subsequent formation of nodose intracellular IH in a sweetpotato leaf cell observed with scanning electron microscopy (SEM). C, IH in leaf cells near peltate glandular trichomes and $\mathbf{D}$, in cells adjacent to leaf veins. B to D, Labels and arrows in black color denote intracellular IH and the ones in white indicate intercellular IH. E, IH grow along adjacent leaf veins. F, Intercellular hyphae under epidermis grow out of stoma on leaf. Images shown in A, B, E, and F were taken with SEM and images in C and D were taken with light microscope. A to C show the inner side of leaf epidermal peel. All images were captured from leaf tissues infected with C. fimbriata BMPZ13 by nonwounding drop inoculation method. P, peltate glandular trichome; RH, runner hyphae; and S, stoma. 
The $C$. fimbriata species complex specialized for infection of sweetpotato is an economically important pathogen and a major factor in postharvest infection leading to both significant yield losses and a marked decrease in storage root quality (Baker et al. 2003). The toxic phytoalexin, ipomeamarone, produced in sweetpotato storage roots in response to $C$. fimbriata infection is a serious health concern for humans as well as livestock (Akazawa and Wada 1961; Imaseki and Ikuzo 1964). To date, it has remained largely unclear how this specialized pathogen might infect host tissues during the vegetative growth of sweetpotato, which would potentially constitute an important component of disease cycle. Here we determined that besides storage roots, $C$. fimbriata can also effectively infect vegetative tissues of sweetpotato through wounds and in the absence of wounds. Previously, only necrotic lesion symptoms of stems of sweetpotato vines were reported in greenhouse trials (Stahr and Quesada-Ocampo 2019). Our pathogenicity assays demonstrated $C$. fimbriata BMPZ13 caused necrotic diseases on sprouts, leaves, and stems when inoculated through wounds and in the absence of wounds. We show C. fimbriata is a versatile pathogen deploying a unique strategy to infect live sweetpotato vegetative tissues in the absence of wounding. C. fimbriata BMPZ13 shares similar characteristics with hemibiotrophic pathogenesis, but its infection strategy also has distinctive features (Presti et al. 2015; van Kan 2006). Hemibiotrophs such as M. oryzae or Colletotrichum spp., produce domeshaped and melanized appressoria responsible for mechanical entry into the host, utilizing the accumulation of turgor pressure to penetrate the cuticle (Tucker and Talbot 2001). Similar to phytopathogenic necrotrophs, $C$. fimbriata BMPZ13 does not form appressorium-like structures for penetration, even though in rare cases inconspicuous enlarged tips were seen (Fig. 3B), but possess the ability to promote direct cell entry through the sweetpotato cuticle (Fig. 3) (Presti et al. 2015).

Our observations support a two-step biotrophic infection for C. fimbriata that is strikingly different from those of classical necrotrophs, which develop only intercellular IH after cell entry through the cuticle. Initial intercellular IH of $C$. fimbriata BMPZ13 form after penetration and grow among epidermal cells, subsequently entering living cells to form intracellular IH (Fig. 4), which is characteristic of pathogenic fungal biotrophic growth (Presti et al. 2015). The ability to form both intercellular and intracellular $\mathrm{IH}$ among or within live cells indicates that C. fimbriata BMPZ13 has a typical biotrophic phase during the early stage ( 3 to 5 days after inoculation) of vegetative tissue infection (Fig. 4 and Supplementary Fig. S4). In contrast, pathogenic necrotrophs continue with the necrotrophic phase, killing host cells after a short biotrophic phase of intercellular IH (Oliver and Ipcho 2004).

C. fimbriata appears to have evolved a lifestyle more similar to that of hemibiotrophs, with a two-step biotrophic phase coupled with a necrotrophic phase of infected tissues, where host cell death is mainly associated with leaf veins. This two-step biotrophic phase is distinct from that of typical hemibiotrophs, which involves rapid development of intracellular IH structures following appressoriummediated penetration (Presti et al. 2015).

For initial infection, $C$. fimbriata does not penetrate stoma openings. This is in contrast to facultative biotrophs, including Passalora fulva (Cladosporium fulvum), which favors stomatal entry for primary infection (De Wit 1977), together with many other fungal pathogens (Presti et al. 2015). In addition to direct entry through the cuticle, our results demonstrated that $C$. fimbriata is also capable of entering sweetpotato tissues through peltate glandular trichomes (Figs. 3, 4, and 5; Table 2), indicating C. fimbriata targets peltate glandular trichomes for infection, a unique strategy for a fungal pathogen that has not been reported previously.

This suggests peltate glandular trichomes are a novel target for infection and $C$. fimbriata utilizes a specialized strategy for pathogenesis of sweetpotato vegetative tissues, which is radically different from any known mechanisms employed by other fungal
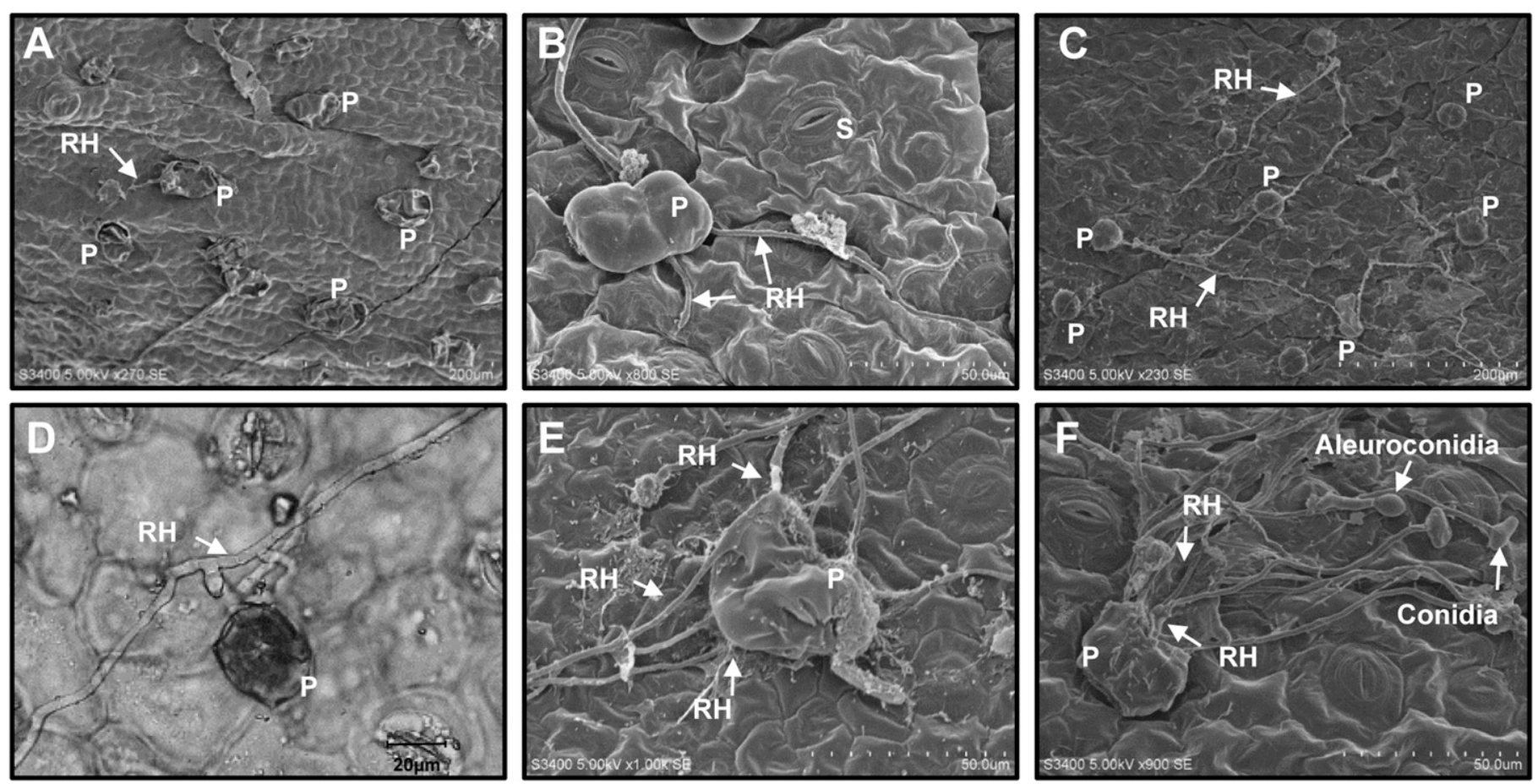

Fig. 5. Peltate glandular cells are targets of Ceratocystis fimbriata BMPZ13 hyphae during the infection process. A, Hyphae grow toward peltate glandular trichomes. B, Hyphae penetrate a peltate glandular trichome. C, Hyphae form a network associated with peltate glandular trichomes. D to F, Runner hyphae accumulate near peltate glandular trichomes on the leaf epidermis of sweetpotato leading to destruction of these structures. All images were captured from leaf tissues infected with $C$. fimbriata BMPZ13 by a nonwounding drop inoculation method. H, hyphae; P, peltate glandular trichomes; RH, runner hyphae; and S, stoma. 
pathogens (Presti et al. 2015). Unlike nonglandular trichomes, peltate glandular trichomes are specialized secretory structures that produce, store, and secrete metabolites, including volatile as well as nonvolatile chemicals and essential oils (Glas et al. 2012; Li et al. 2009, 2014). Glandular trichomes are common structures found in approximately $30 \%$ of all vascular plants (Duncan 1973; Glas et al. 2012; McDonald and Austin 1990). Trichomes are thought to be involved in plant defense (Levin 1973): nonglandular trichomes serve as physical barriers to thwart insects, while glandular trichomes provide a complementary chemical barrier against attempted pathogen ingress (Glas et al. 2012; Levin 1973; Weinhold and Baldwin 2011). A particularly prominent class of secondary metabolites secreted by glandular trichomes include terpenoids, which typically have defensive functions against herbivorous insects in addition to fungal pathogens (Carter et al. 1989; Langenheim 1994; Mayer 2006; Weinhold and Baldwin 2011). In this context, ipomeamarone is a furanoterpenoid and thus may also be produced in sweetpotato glandular trichomes.

Interestingly, the clavicipitaceous endophytic fungus, Periglandula ipomoeae, establishes a symbiotic relationship with Ipomoea asarifolia, a plant from the family Convolvulaceae, and the mycelium of $P$. ipomoeae localizes to peltate glandular trichomes that may strengthen its association with host tissues (Leistner and Steiner 2009, 2018; Steiner et al. 2006, 2011). In addition, it has been postulated that peltate glandular trichome-secreted metabolites might constitute a source of nutrients for these fungi (Steiner et al. 2008). Thus, C. fimbriata may exploit sweetpotato glandular trichomes in a similar manner to promote successful pathogenesis. The unique behavior of $C$. fimbriata entering peltate glandular trichomes dramatically contrasts to the infection strategies of other pathogenic or symbiotic fungi that enter the host plant by either direct cell penetration or via stomatal openings (Presti et al. 2015), suggesting C. fimbriata may have evolved a distinct mechanism of infection that targets the specialized secretory structures of its host.

Compared with the rot of storage roots, vegetative tissues of sweetpotato spray-infected with $C$. fimbriata BMPZ13 produce fewer macroscopic lesions than typical necrotrophs. Infection by C. fimbriata BMPZ13 lead to gradual chlorosis of the whole leaf, while infected seedling cuttings developed black rot on the stem base, followed by chlorosis and eventual wilt of entire branches 11 to 22 days after inoculation (Fig. 2B), similar to those caused by C. fimbriata on the Peruvian carrot (Arracacia xanthorrhiza), a nonwoody herbaceous host (Melo et al. 2016). For woody plants, wilt and canker caused by the $C$. fimbriata complex produces similar symptoms in kiwifruit (Actinidia spp.) (Piveta et al. 2016), mango (Mangifera indica L.) (Oliveira et al. 2015), pomegranate (Huang et al. 2003; Somasekhara 1999), plane tree (Platanus spp.) (Clerivet et al. 2000), and Caryocar brasiliense trees (da Silva et al. 2017). Wilt and subsequent plant death appears to be associated with colonization of the xylem, which may result in blockage of the vascular tissue (Araujo et al. 2014, 2016). Our results show that inoculation at wound sites enabled $C$. fimbriata BMPZ13 to form necrotrophic hyphae along veins, which likely progressed through the vascular system. We posit that $C$. fimbriata is a specialized vascular-associated pathogen, as evidenced by necrotic lesions that extended to surrounding leaf veins, damaging the vascular system (Fig. 4). Cytohistological observations showed intercellular IH grew rapidly within veins, facilitating necrotrophic growth marked by extensive necrosis in veins. This is consistent with $C$. fimbriata being a vascular pathogen on sweetpotato vegetative tissue (Fig. 4).

Our data also indicate a role for iron in $C$. fimbriata pathogenesis, although the underlying mechanism remains to be established (Verbon et al. 2017). In this context, iron-associated ferroptosis was observed, which has also recently been reported during an incompatible interaction of Magnaporthe oryzae with rice (Dangol
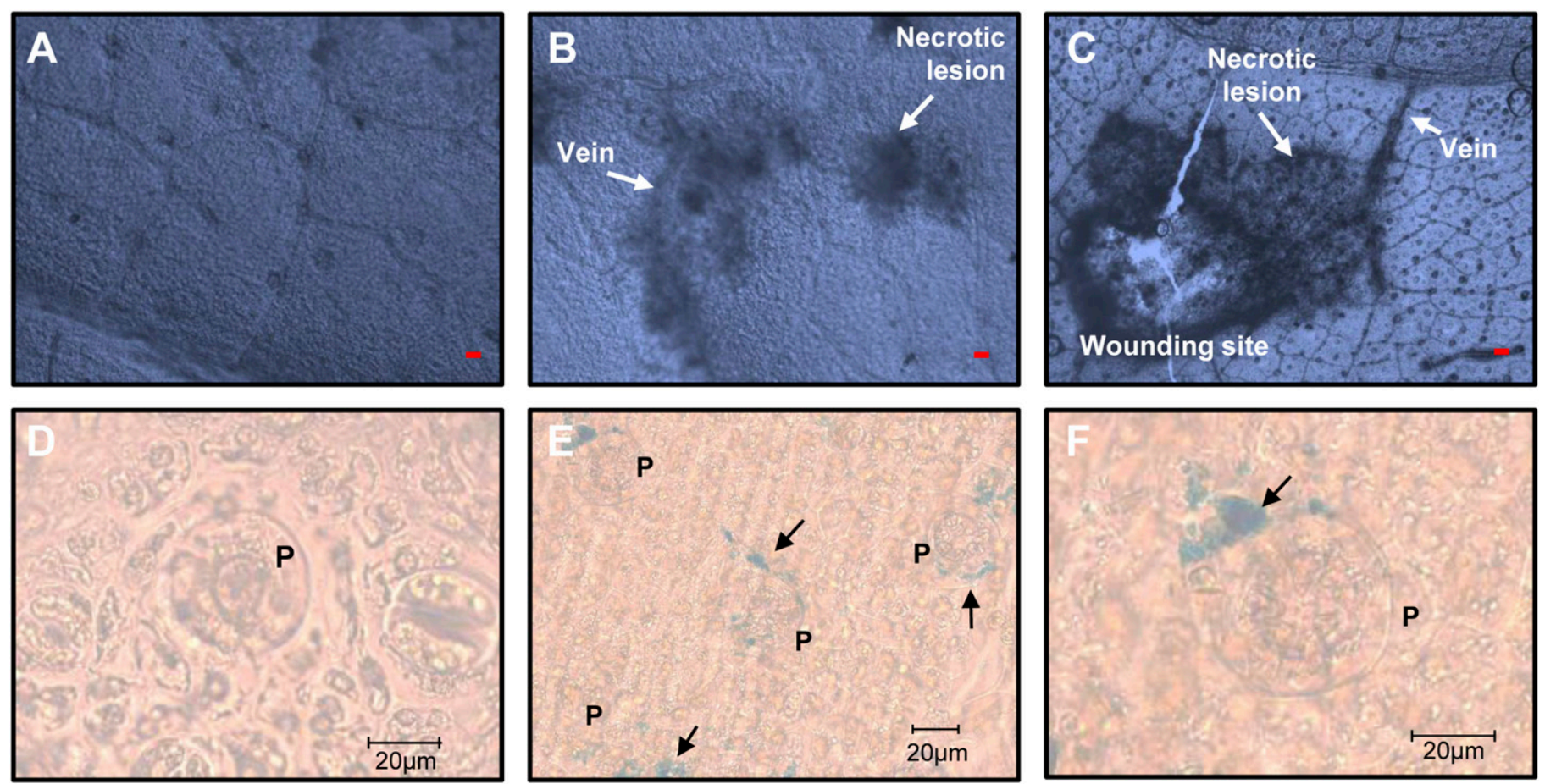

Fig. 6. Ceratocystis fimbriata BMPZ13 infection leads to necrosis and ferric accumulation in infected leaf tissues. A, Mock inoculated leaf. B, Necrotic lesion on leaf following nonwound drop inoculation of C. fimbriata BMPZ13. C, Lesion at wound inoculation site and vein necrosis on leaf tissues. D, Mock inoculation does not result in pigment formation in uninfected cells near peltate glandular trichomes. E, Infected peltate glandular trichomes and cells around these structures of leaf tissues form blue pigments derived from Prussian blue staining reporting ferric iron accumulation. F, An enlarged area showing infected leaf cells with blue pigment accumulation resulting from Prussian blue staining. Shown in A, B, D, E, and F are infected leaf tissues by nonwounding drop inoculation method with either $\mathrm{H}_{2} \mathrm{O}$ (A and D) or C. fimbriata BMPZ13 (B, E, and F). Shown in C is infected leaf tissue by wounding drop inoculation method. Arrows indicate ferric iron accumulation marked by Prussian blue staining. In A to $\mathrm{C}$, bar $=40 \mu \mathrm{m}$. 
et al. 2019). In contrast, our data show a role for iron-associated ferroptosis during a compatible interaction of $C$. fimbriata with sweetpotato, suggesting the underlying mechanism of iron involvement in cell death associated with necrotrophic growth of $C$. fimbriata is distinct from that of $M$. oryzae triggered during the immune response. Collectively, our findings establish a novel mechanism of fungal pathogenesis: infection of peltate glandular trichomes. This data may help guide future control strategies for C. fimbriata infection of sweetpotato.

\section{LITERATURE CITED}

Akazawa, T., and Uritani, I. 1961. Pattern of carbohydrate breakdown in sweet potato roots infected by Ceratocystis fimbriata. Agric. Biol. Chem. 25: 873-875.

Akazawa, T., and Wada, K. 1961. Analytical study of Ipomeamarone and chlorogenic acid alterations in sweet potato roots infected by Ceratocystis fimbriata. Plant Physiol. 36:139-144.

Altschul, S. F., Gish, W., Miller, W., Myers, E. W., and Lipman, D. J. 1990. Basic local alignment search tool. J. Mol. Biol. 215:403-410.

Araujo, L. 2014. Histopathology of mango - Ceratocystis fimbriata interaction. Ph.D. thesis. Universidade Federal de Viçosa.

Araujo, L., Bispo, W. M., Cacique, I. S., Moreira, W. R., and Rodrigues, F. A. 2014. Resistance in mango against infection by Ceratocystis fimbriata. Phytopathology 104:820-833.

Araujo, L., Bispo, W. M. S., Rios, J. A., Fernandes, S. A., and Rodrigues, F. D. 2016. Alkaloids and phenolics biosynthesis increases mango resistance to infection by Ceratocystis fimbriata. Bragantia 75:199-211.

Baker, C. J., Harrington, T. C., Krauss, U., and Alfenas, A. C. 2003. Genetic variability and host specialization in the Latin American clade of Ceratocystis fimbriata. Phytopathology 93:1274-1284.

Cai, L., Jiang, G., Zheng, S., and Hu, Z. 2008. Observation of glandular hairs morphology on tobacco leaves by scanning electron microscopy. Chin. Agric. Sci. Bull. 24:110-113.

Carter, C. D., Gianfagna, T. J., and Sacalis, J. N. 1989. Sesquiterpenes in glandular trichomes of a wild tomato species and toxicity to the Colorado potato beetle. J. Agric. Food Chem. 37:1425-1428.

Clark, C. A., and Moyer, J. W. 2013. Black rot. Pages 29-33 in: Compendium of Sweetpotato Diseases, Pests, and Disorders Compendium of Sweetpotato Diseases, Pests, and Disorders. C. A. Clark, D. M. Ferrin, T. P. Smith, and G. J. Holmes, eds. American Phytopathological Society, St. Paul, MN.

Clerivet, A., Deon, V., Alami, I., Lopez, F., Geiger, J. P., and Nicole, M. 2000. Tyloses and gels associated with cellulose accumulation in vessels are responses of plane tree seedlings (Platanus $\times$ acerifolia) to the vascular fungus Ceratocystis fimbriata f. sp. platani. Trees-Struct Funct 15:25-31.

Coxon, D. T., Curtis, R. F., and Howard, B. 1975. Ipomeamarone, a toxic furanoterpenoid in sweet potatoes (Ipomea batatas) in the United Kingdom. Food Cosmet. Toxicol. 13:87-90.

da Silva, A. C., Candido, T. S., Sales, N. L. P., Harrington, T. C., and Alfenas, A. C. 2017. First report of Ceratocystis wilt caused by Ceratocystis fimbriata on Caryocar brasiliense trees in Brazil. Plant Dis. 101:1822.

Dangol, S., Chen, Y., Hwang, B. K., and Jwa, N.-S. 2019. Iron- and reactive oxygen species-dependent ferroptotic cell death in rice-Magnaporthe oryzae interactions. Plant Cell 31:189-209.

De Wit, P. J. G. M. 1977. A light and scanning-electron microscopic study of infection of tomato plants by virulent and avirulent races of Cladosporium fulvum. Neth. J. Plant Pathol. 83:109-122.

Dos Santos, A. F., Ferreira, M. A., Auer, C. G., Buhrer, C. B., Brito, N. M., Scremin, R. M., and Mireski, M. C. 2018. First report of yerba mate wilt caused by Ceratocystis fimbriata in Brazil. Plant Dis. 102:2381.

Duncan, E. J. 1973. Anomalous growth in the stem of Ipomoea batatas (L.) Lam. infested with Megastes larvae. Ann. Bot. (Lond.) 37:981-985.

Engelbrecht, C. J. B., Harrington, T. C., Steimel, J., and Capretti, P. 2004. Genetic variation in eastern North American and putatively introduced populations of Ceratocystis fimbriata f. platani. Mol. Ecol. 13: 2995-3005.

Glas, J. J., Schimmel, B. C., Alba, J. M., Escobar-Bravo, R., Schuurink, R. C., and Kant, M. R. 2012. Plant glandular trichomes as targets for breeding or engineering of resistance to herbivores. Int. J. Mol. Sci. 13: 17077-17103

Harrington, T. C., Huang, Q., Ferreira, M. A., and Alfenas, A. C. 2015. Genetic analyses trace the Yunnan, China population of Ceratocystis fimbriata on pomegranate and taro to populations on Eucalyptus in Brazil. Plant Dis. 99:106-111.

Harrington, T. C., Thorpe, D. J., Marinho, V. L. A., and Furtado, E. L. 2005. First report of black rot of Colocasia esculenta caused by Ceratocystis fimbriata in Brazil. Fitopatol. Bras. 30:88-89.
Hildebrand, E. M., and Cook, H. T. 1959. Black rot. Pages 6-7 in: Sweetpotato Diseases. Farmers' Bulletin No. 1059. U.S. Department of Agriculture, Washington, D.C.

Huang, Q., Zhu, Y. Y., Chen, H. R., Wang, Y. Y., Liu, Y. L., Lu, W. J., and Ruan, X. Y. 2003. First report of pomegranate wilt caused by Ceratocystis fimbriata in Yunnan, China. Plant Dis. 87:1150.

Imaseki, U., and Ikuzo, H. 1964. Ipomeamarone accumulation and lipid metabolism in sweet potato infected by the black rot fungus II. Accumulation mechanism of ipomeamarone in the infected region with special regard to contribution of the non-infected tissue. Plant Cell Physiol. 5:133-143.

Johnson, J. A., Harrington, T. C., and Engelbrecht, C. J. 2005. Phylogeny and taxonomy of the North American clade of the Ceratocystis fimbriata complex. Mycologia 97:1067-1092.

Joo, J. H., Wang, S., Chen, J. G., Jones, A. M., and Fedoroff, N. V. 2005. Different signaling and cell death roles of heterotrimeric $\mathrm{G}$ protein $\alpha$ and $\beta$ subunits in the Arabidopsis oxidative stress response to ozone. Plant Cell 17:957-970.

Kabbage, M., Yarden, O., and Dickman, M. B. 2015. Pathogenic attributes of Sclerotinia sclerotiorum: switching from a biotrophic to necrotrophic lifestyle. Plant Sci. 233:53-60.

Koch, E., and Slusarenko, A. 1990. Arabidopsis is susceptible to infection by a downy mildew fungus. Plant Cell 2:437-445.

Langenheim, J. H. 1994. Higher plant terpenoids: A phytocentric overview of their ecological roles. J. Chem. Ecol. 20:1223-1280.

Lebot, V. 2009. Tropical Root and Tuber Crops: Cassava, Sweet Potato, Yams and Aroids. CABI Publishing Group, Wallingford, U.K.

Leistner, E., and Steiner, U. 2009. Fungal origin of ergoline alkaloids present in dicotyledonous plants (Convolvulaceae). Pages 197-208 in: Physiology and Genetics: Selected Basic and Applied Aspects. T. Anke and D. Weber, eds. Springer, Berlin, Heidelberg.

Leistner, E., and Steiner, U. 2018. The genus Periglandula and its symbiotum with morning glory plants (Convolvulaceae). Pages 131-147 in: Physiology and Genetics: Selected Basic and Applied Aspects. Springer, Berlin, Heidelberg.

Levin, D. A. 1973. The role of trichomes in plant defense. Q. Rev. Biol. 48: 3-15.

Li, C. H., Liu, Y., Hua, J., Luo, S. H., and Li, S. H. 2014. Peltate glandular trichomes of Colquhounia seguinii harbor new defensive clerodane diterpenoids. J. Integr. Plant Biol. 56:928-940.

Li, Q., Deng, J., Yang, M., and Li, J.-Q. 2009. The comparative study on biological characteristics of Ceratocystis fimbriata isolates causing pomegranate wilt and sweet potato black rot. Mycosystema 28:189-196.

Li, Q., Harrington, T., and Li, J. 2016a. Worldwide distribution of the sweet potato strains of Ceratocystis fimbriata. (Abstr.) Phytopathology 106(suppl.). https://www.apsnet.org/meetings/Documents/2016_meeting_ abstracts/aps2016_88.htm

Li, Q., Harrington, T. C., McNew, D., Li, J. Q., Huang, Q., Somasekhara, Y. M., and Alfenas, A. C. 2016b. Genetic bottlenecks for two populations of Ceratocystis fimbriata on sweet potato and pomegranate in China. Plant Dis. 100:2266-2274.

Lim, T. K. 2016. Ipomoea batatas. Pages 91-171 in: Edible Medicinal and Non-Medicinal Plants: Modified Stems, Roots, Bulbs, vol. 10. Springer Science+Business Media, Dordrecht.

Liu, G., Greenshields, D. L., Sammynaiken, R., Hirji, R. N., Selvaraj, G., and Wei, Y. 2007. Targeted alterations in iron homeostasis underlie plant defense responses. J. Cell Sci. 120:596-605.

Liu, Y., Jing, S.-X., Luo, S.-H., and Li, S.-H. 2019. Non-volatile natural products in plant glandular trichomes: chemistry, biological activities and biosynthesis. Nat. Prod. Rep. 36:626-665.

Mayer, A. M. 2006. Polyphenol oxidases in plants and fungi: Going places? A review. Phytochemistry 67:2318-2331.

McDonald, J. A., and Austin, D. F. 1990. Changes and additions in ipomoea section batatas (Convolvulaceae). Brittonia 42:116-120.

Melo, M. P., Pimenta, L., Oliveira, L. S. S., and Ferreira, M. A. 2016. First report of Ceratocystis fimbriata causing black rot on Arracacia xanthorrhiza in Brazil. Plant Dis. 100:652-653.

Murray, M. G., and Thompson, W. F. 1980. Rapid isolation of high molecular weight plant DNA. Nucleic Acids Res. 8:4321-4326.

Oguni, I., and Uritani, I. 1974. Dehydroipomeamarone as an intermediate in biosynthesis of Ipomeamarone, a phytoalexin from sweet-potato root infected with Ceratocystis fimbriata. Plant Physiol. 53:649-652.

Oliveira, L. S. S., Harrington, T. C., Ferreira, M. A., Damacena, M. B., Al-Sadi, A. M., Al-Mahmooli, I. H. S., and Alfenas, A. C. 2015. Species or genotypes? Reassessment of four recently described species of the Ceratocystis wilt pathogen, Ceratocystis fimbriata, on Mangifera indica. Phytopathology 105:1229-1244.

Oliver, R. P., and Ipcho, S. V. 2004. Arabidopsis pathology breathes new life into the necrotrophs-vs.-biotrophs classification of fungal pathogens. Mol. Plant Pathol. 5:347-352. 
Panda, V., and Sonkamble, M. 2012. Phytochemical constituents and pharmacological activities of Ipomoea batatas L. (Lam)-A review. Int. J. Res. Phytochem. Pharmacol. 2:25-34.

Pasura, A., and Harrington, T. C. 2004. Two undescribed species in the Ceratocystis fimbriata complex on Ficus and Colocasia from Asia and Polynesia. Phytopathology 94(suppl.):S160-S161.

Paul, N. C., Nam, S.-S., Kachroo, A., Kim, Y.-H., and Yang, J.-W. 2018. Characterization and pathogenicity of sweet potato (Ipomoea batatas) black rot caused by Ceratocystis fimbriata in Korea. Eur. J. Plant Pathol. 152:833-840.

Piveta, G., Ferreira, M. A., Muniz, M. F. B., Valdetaro, D., ValdebenitoSanhueza, R., Harrington, T., and Alfenas, A. C. 2016. Ceratocystis fimbriata on kiwifruit (Actinidia spp.) in Brazil. N.Z. J. Crop Hortic. 44:13-24.

Presti, L. L., Lanver, D., Lozada-Ramirez, J., Schweizer, G., Tanaka, S., Liang, L., Tollot, M., Zuccaro, A., Reissmann, S., and Kahmann, R. 2015. Fungal effectors and plant susceptibility. Annu. Rev. Plant Biol. 66:513-545.

Qiu, H., Huang, J., Yang, J., Rozelle, S., Zhang, Y., Zhang, Y., and Zhang, Y. 2010. Bioethanol development in China and the potential impacts on its agricultural economy. Appl. Energy 87:76-83.

Scott, G. J., Best, R., Rosegrant, M., and Bokanga, M. 2000. Roots and tubers in the global food system: A vision statement to the year 2020. A copublication of the International Potato Center (CIP), Centro Internacional de Agricultura Tropical (CIAT), International Food Policy Research Institute (IFPRI), International Institute of Tropical Agriculture (IITA), and International Plant Genetic Resources Institute (IPGRI), Printed in Lima. International Potato Center, Peru.

Somasekhara, Y. M. 1999. New record of Ceratocystis fimbriata causing wilt of pomegranate in India. Plant Dis. 83:400.

Stahr, M. N., and Quesada-Ocampo, L. M. 2019. Black rot of sweetpotato: A comprehensive diagnostic guide. Plant Health Prog. 20:255-260.

Steiner, U., Ahimsa-Müller, M. A., Markert, A., Kucht, S., Groß, J., Kauf, N., Kuzma, M., Zych, M., Lamshöft, M., and Furmanowa, M. 2006. Molecular characterization of a seed transmitted clavicipitaceous fungus occurring on dicotyledoneous plants (Convolvulaceae). Planta 224:533-544.

Steiner, U., Hellwig, S., and Leistner, E. 2008. Specificity in the interaction between an epibiotic clavicipitalean fungus and its convolvulaceous host in a fungus/plant symbiotum. Plant Signal. Behav. 3:704-706.

Steiner, U., Leibner, S., Schardl, C. L., Leuchtmann, A., and Leistner, E. 2011. Periglandula, a new fungal genus within the Clavicipitaceae and its association with Convolvulaceae. Mycologia 103:1133-1145.
Stielow, J. B., Levesque, C. A., Seifert, K. A., Meyer, W., Iriny, L., Smits, D., Renfurm, R., Verkley, G., Groenewald, M., and Chaduli, D. 2015. One fungus, which genes? Development and assessment of universal primers for potential secondary fungal DNA barcodes. Persoonia. Mol. Phylogeny Evol. Fungi 35:242-263.

Takemoto, D., Jones, D. A., and Hardham, A. R. 2003. GFP-tagging of cell components reveals the dynamics of subcellular re-organization in response to infection of Arabidopsis by oomycete pathogens. Plant J. 33: 775-792.

Tamura, K., Stecher, G., Peterson, D., Filipski, A., and Kumar, S. 2013. MEGA6: Molecular evolutionary genetics analysis version 6.0. Mol. Biol. Evol. 30:2725-2729.

Tucker, S. L., and Talbot, N. J. 2001. Surface attachment and pre-penetration stage development by plant pathogenic fungi. Annu. Rev. Phytopathol. 39: $385-417$.

van Kan, J. A. 2006. Licensed to kill: The lifestyle of a necrotrophic plant pathogen. Trends Plant Sci. 11:247-253.

Verbon, E. H., Trapet, P. L., Stringlis, I. A., Kruijs, S., Bakker, P., and Pieterse, C. M. J. 2017. Iron and immunity. Annu. Rev. Phytopathol. 55:355-375.

Wamalwa, L. N., Cheseto, X., Ouna, E., Kaplan, F., Maniania, N. K., Machuka, J., Torto, B., and Ghislain, M. 2015. Toxic Ipomeamarone accumulation in healthy parts of sweetpotato (Ipomoea batatas L. Lam) storage roots upon infection by Rhizopus stolonifer. J. Agric. Food Chem. 63:335-342.

Wang, M., Shi, Y., Xia, X., Li, D., and Chen, Q. 2013. Life-cycle energy efficiency and environmental impacts of bioethanol production from sweet potato. Bioresour. Technol. 133:285-292.

Weinhold, A., and Baldwin, I. T. 2011. Trichome-derived O-acyl sugars are a first meal for caterpillars that tags them for predation. Proc. Natl. Acad. Sci. 108:7855-7859

Xie, Z.-S., Du, H.-R., Li, J.-B., and Bondada, B. 2018. Morphological and structural changes of stomata and leaf veins during growth of grape leaves using tissue clearing technique. Plant Physiol. J. 54:237-246.

Zauza, E. A. V., Alfenas, A. C., Harrington, T. C., Mizubuti, E. S., and Silva, J. F. 2004. Resistance of Eucalyptus clones to Ceratocystis fimbriata. Plant Dis. 88:758-760.

Zhang, D., Wang, Y., Wang, S., Bai, R., and Zhang, Z. 2017. Efficacy of 9 biological reagents to control sweet potato black rot. Chin. J. Biol. Control 33:681-685 